\title{
THE USE OF ICT BY HIGH SCHOOL STUDENTS IN THE FAMILY. MODELS AND OPTIONS FOR THE WEEKEND
}

\author{
Dorin OPRIŞ, Ph.D. \\ „1 Decembrie 1918” University of Alba Iulia \\ dorin_monica@yahoo.com
}

\begin{abstract}
The use of ICT by high school students in the family. Models and options for the weekend. The development of the technology lying at the base of ITC led to changes not only in society and education, but in the case of family, it brought about challenges hard to anticipate a few decades before. The present study aims at identifying the main elements that define the use of ITC in the family, at the weekend. We analyzed data collected from a sample of high school students, concerning the preference for various activities that include or take advantage of means of communication. Due to the complexity of the issue, we made analyses based on gender, in relation to the age of the respondents, to their residence, to the family extension, starting from their religious affiliation or confession, as well as to their education level.
\end{abstract}

Keywords: ICT, family structure, communication, high school students, education

\section{Preliminaries}

Any analysis connected to the importance of using the new technologies in order to improve the quality of education also represents a reconfirmation of the need to make educational research meant to offer diagnosis and solutions in order to valorize in a proper pedagogical way, on the one hand, the opportunities offered by these modern means, and on the other hand, the preoccupation of the children, starting from an early age, for everything that means digital area.

In this paper we present the data collected from an investigation based on questionnaires, which aimed at identifying answers to a few questions regarding the presence and the possible impact of information and communication technology on the life of adolescents. Thus, we intend to discover the place occupied by communication with friends using the 
Internet and phone in the preferences of high school students during the weekend, respectively the amount of time spent with modern information means.

The sample of the research included 802 high school students, divided in four age groups, between 15 and 18, balanced from the point of view of gender $(50,37 \%$ girls and $49,63 \%$ boys), from the point of view of residence $(50,62 \%$ from the urban area and $49,38 \%$ from the rural area). As for the religious affiliation of the students'families, the sample respects the distribution at a national level in Romania of the religions and cults recognized legally. We also had in mind the education level of students, following a structure with three levels: 5-6,99 (11,48\%), 7-8,99 (55,23\%), 9$10(33,29 \%)$. Starting from the fact that spending free time depends on the extension of the family, in the sample we chose we have the following data: a single child in the family, $(23,19 \%)$, two children in the family $(46,99 \%)$, three children in the family $(12,59 \%)$, respectively more than three children in the family $(10,34 \%)$, the percentage up to $100 \%$ being non-answers.

\section{The preference for activities that involve means of communication}

In the questionnaire we offered, the students were asked to choose from a list of ten activities they can do at the weekend three they prefer, without making a hierarchy. Among the ten activities, three were in direct relation to the means of communication (television and the Internet), being chosen by students in different percentages: watching a show on TV $(27,41 \%)$, communicating with friends online (37\%), respectively reading/documenting Internet resources for current school activities (8,51\%). These values indicate the fact that almost half of the students choose to spend the weekend using at least one of the means of communication we suggested in the administered questionnaire.

In table 1 we presented the situation of the multiple, respectively single choices for the three actions.

\section{Watching a TV show / Communicating with friends online / Documenting Internet resources for current school activities (\%)}

Table 1

\begin{tabular}{|c|c|c|c|}
\hline \multirow{2}{*}{$\begin{array}{c}\text { Documenting Internet resources for } \\
\text { current school activities }\end{array}$} & \multicolumn{2}{|c|}{$\begin{array}{l}\text { Commmunicating } \\
\text { with friends online }\end{array}$} & \multirow{2}{*}{ Total } \\
\hline & $\begin{array}{l}\text { did not } \\
\text { choose }\end{array}$ & chose & \\
\hline
\end{tabular}




\begin{tabular}{|c|c|c|c|c|c|}
\hline \multirow{2}{*}{$\begin{array}{c}\text { did not } \\
\text { choose }\end{array}$} & $\begin{array}{c}\text { Watching a TV } \\
\text { show }\end{array}$ & $\begin{array}{c}\text { did not } \\
\text { choose }\end{array}$ & 48,73 & 23,39 & 72,13 \\
\cline { 2 - 6 } & \multicolumn{2}{|c|}{ Total } & 63,01 & 37 & 100 \\
\cline { 2 - 6 } & \multicolumn{2}{|c|}{ chose } & 14,18 & 13,59 & 27,77 \\
\hline chose & $\begin{array}{c}\text { Watching a TV } \\
\text { show }\end{array}$ & $\begin{array}{c}\text { did not } \\
\text { choose }\end{array}$ & 50 & 26,04 & 76,04 \\
\cline { 2 - 6 } & \multicolumn{2}{|c|}{ chose } & 12,5 & 11,46 & 23,96 \\
\cline { 2 - 6 } & \multicolumn{2}{|c|}{ Total } & 62,5 & 37,5 & 100 \\
\hline
\end{tabular}

Data shows that out of the total of those who chose reading/documenting Internet resources, $11,46 \%$ also chose the other two variants, and $12,5 \%$ of the students chose only watching TV shows. $13,59 \%$ of the students chose the combination between watching TV shows and communicating with friends online, and $14,18 \%$ only watching TV shows.

These results indicate that students prefer to spend the weekend at home using several means of communication. We did not have in mind communication using the phone, which can also occur in an area different from home. Due to the fact that nonformal and informal education through the TV channels was preferred by approximately a quarter of the respondents, we present their options for certain TV shows, in table 2.

Students' option for certain TV shows

Table 2

\begin{tabular}{|l|c|}
\hline Types of TV shows & $\mathbf{\%}$ \\
\hline films & 73,1 \\
\hline entertainment shows & 55,1 \\
\hline music & 54,7 \\
\hline news & 23,8 \\
\hline cultural shows & 16,1 \\
\hline documentaries & 7,1 \\
\hline other shows & 1,86 \\
\hline
\end{tabular}

\section{Data analysis according to different variables}

According to gender, the reference was made to the whole sample, given its structure. In table 2 we synthetized the research results in percentages, referring to the three aspects analyzed. We also calculated the amplitude (A), through the difference between the highest and the lowest 
percentage for the three activities, as well as the percenatge difference girlsboys for each of the three activities.

The preference for different activities at the weekend, Table 3 according to gender (\%)

\begin{tabular}{|l|c|c|c|c|}
\hline Activities & $\begin{array}{c}\text { Watching } \\
\text { TV } \\
\text { shows }\end{array}$ & $\begin{array}{c}\text { Communicating } \\
\text { with friends } \\
\text { online }\end{array}$ & $\begin{array}{c}\text { Documenting } \\
\text { Internet } \\
\text { resources for } \\
\text { school } \\
\text { activities }\end{array}$ & A \\
\hline $\begin{array}{c}\text { Total of } \\
\text { choices }\end{array}$ & $\mathbf{2 7 , 4 1 \%}$ & $\mathbf{3 7 \%}$ & $\mathbf{8 , 5 1 \%}$ & \\
\hline Feminine & 53,37 & 47,65 & 57,27 & 9,62 \\
\hline Masculine & 46,63 & 52,03 & 42,73 & 9,3 \\
\hline $\begin{array}{l}\text { Difference } \\
\text { (G-B) }\end{array}$ & 6,74 & $-4,38$ & 14,54 & \\
\hline
\end{tabular}

The data in table 3 reveal differences according to gender in the preferences of high school students. In the case of girls, the highest percentages are connected with school activities, as for boys, communicating with friends online $(52,03 \%)$ predominates. The amplitude close to 10 percentage points shows the existence of a hierarchy of students'preferences for certain activities. If as concerns watching TV shows, respectively communicating with friends online, the differences are not significant, we notice a difference greater than 10 percentage points as concerns reading/documenting Internet resources for school activities. This difference can be attributed to the well-known meticulousness of girls regarding school activity.

In order to analyze the data according to the students'age, we will make distribution curves for the percentages of the three activities (TV watching TV shows, Netf - communicating with friends online; Nets documenting Internet resources for school activities), present in figure 1. 


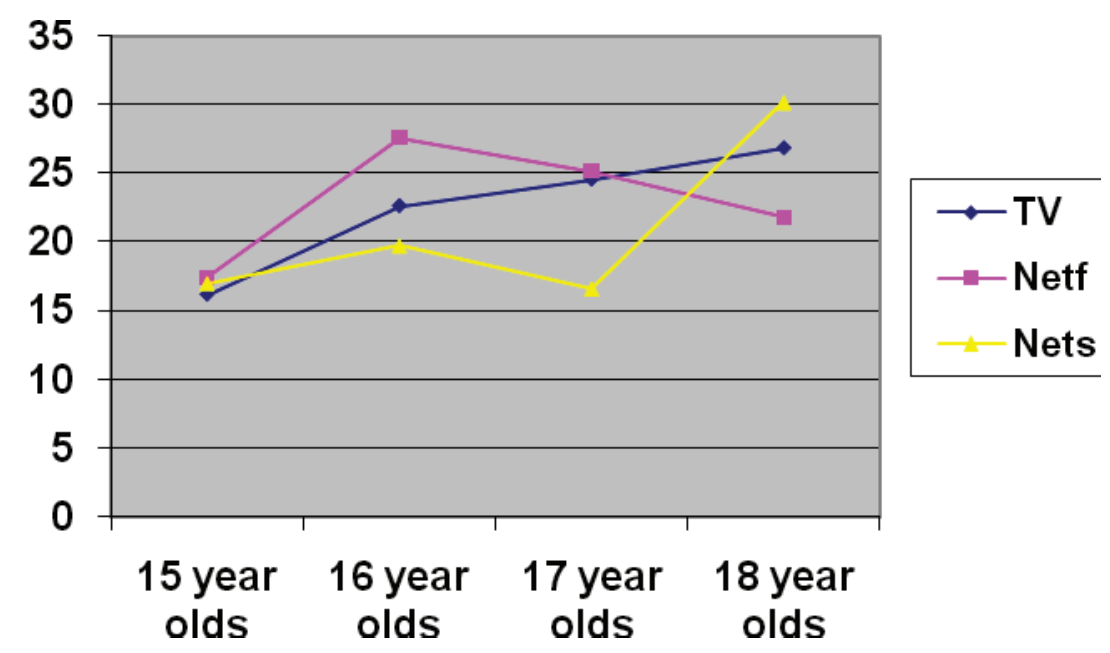

Fig.1. Distribution curves of percentages for students'choices, according to age

The data collected indicate different distributions of the students'choices according to their age. For the first option (TV) we notice an almost lineal rising curve, the amplitude being $\mathrm{A}_{\mathrm{TV}}=26,86 \%-16,48 \%=$ $10,38 \%$, which indicates significant changes between the students' preoccupations in their free time at the beginning of high school compared to the end of it. The same rising tendency is found in the case of the third option (Nets), with an unsignificant decrease in the case of 17 year olds. In the case of 18 year olds, who prepare for the final exam we find an increase with almost 16 percentage points. As for the second option (Netf), we notice that the 16-year old students have a tendency 10 percentage points greater to communicate with friends on the Internet, compared to the 15 year olds. Towards the end of school years one notices a decrease in this preoccupation, being surpassed by the one referring to watching TV shows, respectively documenting for school activities.

If we were to characterize the students according to categories, we can say that, when they are 15 , they are equally preoccupied by television, the dialogue with their friends and documenting Internet resources for school activities, but these preoccupations are not very present in their lives (percentages below 20\%). When they are 16, age which corresponds to the eleventh grade, marked by the crisis of adolescence at multiple levels, there is an increase of the desire to communicate with friends, not necessarily face to face, in the case of more than a quarter of the respondents. The 17 year olds have preoccupations similar to those of 16 year olds, a little diminished, so that when they are 18 , the Internet has a more important role in their 
school education. The growingly important place occupied by television in the life of high school students, as they grow up, can also be a consequence of the fact that the weekend is considered by many as a period of relaxation, and the offer made through the multitude of TV stations is very generous in this respect. On the other hand, in some families, spending many hours a day with the TV on represents a fact, and for the students a fact of life.

Another important variable in identifying some aspects linked to spending the weekend is represented by the residence milieu of the respondents. As we have already mentioned, in the sample we selected the percentage of students in the urban area is almost equal. We related to the total number of students in each category, the data being presented in table 4 .

The preference for certain activities at the weekend, according to the residence milieu (\%)

\begin{tabular}{|l|c|c|c|c|}
\hline \multicolumn{1}{|c|}{$\begin{array}{l}\text { Activities } \\
\text { The residence } \\
\text { milieu }\end{array}$} & $\begin{array}{c}\text { Watching } \\
\text { TV shows }\end{array}$ & $\begin{array}{c}\text { Communication } \\
\text { with friends } \\
\text { online }\end{array}$ & $\begin{array}{c}\text { Documenting } \\
\text { Internet } \\
\text { resources for } \\
\text { school } \\
\text { activities }\end{array}$ & $\mathbf{A}$ \\
\hline \multicolumn{1}{|c|}{ Total choices } & $\mathbf{2 7 , 4 1 \%}$ & $\mathbf{3 7 \%}$ & $\mathbf{8 , 5 1 \%}$ & \\
\hline Urban & 50,09 & 56,59 & 51,04 & 6,5 \\
\hline Rural & 49,91 & 43,41 & 49,96 & 6,55 \\
\hline Difference (U-R) & 0,81 & 13,18 & 1,08 & \\
\hline
\end{tabular}

The analysis of the data in table indicates, in the case of two of the three activities of spending free time at the weekend we observed in our research, the tendency to a diminution of the differences urban-rural. Besides, this fact is to be found in a growing number of aspects of life, highlighted by the pedagogical research of recent years ${ }^{14}$.

\footnotetext{
${ }^{14}$ For example, the research of recent years show a decrease of the percentage of participation with a monthly frequency at the services of one's own religious confession in the rural area and an increase in the urban area, which led to the attenuation of the differences according to this variable, in the case of Romanians. One also notices that the population for which religious effectivity is a main element of life is younger. (Mălina Voicu ed., Credinţă şi practică religioasă în România (Religious faith and practice in Romania),Institutul de Cercetare a Calităţii Vieții, Grupul românesc pentru studiul valorilor sociale, "Valorile românilor", Newsletter, nr. 2, February, 2009, pp. 1-2).
} 
The option for communicating with friends differs according to the residence milieu in a significant percentage from a statistical point of view (over 10 percentage points.) This fact shows the tendency, more reduced in the case of towns compared to the case of villages, to be in communion, to meet friends face to face. The virtual reality tends to make people lonely, especially in towns. The advantages offered by life in the rural area, such as observing traditions, feasts, valorizing family and friends are highlighted by the results of the present research, too.

The options regarding the way of spending free time are strongly influenced by the extension of the family, this being one of the variables taken into consideration when analyzing the data. Table 5 presents the results obtained by relating to the total number of respondents in each category. We also calculated the amplitude for each type of activity.

The preference for certain activities at the weekend, according to the extension of the family (\%) Table 5

\begin{tabular}{|l|c|c|c|}
\hline $\begin{array}{l}\text { Number of } \\
\text { children }\end{array}$ & $\begin{array}{c}\text { Watching } \\
\text { TV shows }\end{array}$ & $\begin{array}{c}\text { Communication } \\
\text { with friends } \\
\text { online }\end{array}$ & $\begin{array}{c}\text { Documenting } \\
\text { Internet } \\
\text { resources for } \\
\text { school } \\
\text { activities }\end{array}$ \\
\hline \multicolumn{1}{|c|}{ Total choices } & $\mathbf{2 7 , 4 1 \%}$ & $\mathbf{3 7 \%}$ & $\mathbf{8 , 5 1 \%}$ \\
\hline a single child & 32 & 41,52 & 11,03 \\
\hline two children & 28,5 & 36,98 & 7,43 \\
\hline three children & 21,01 & 36,95 & 7,97 \\
\hline $\begin{array}{l}\text { more than three } \\
\text { children }\end{array}$ & 16,27 & 26,35 & 8,57 \\
\hline Amplitude & 15,73 & 14,17 & 3,7 \\
\hline
\end{tabular}

Based on the data in table 5, we made distribution curves of the data for each of the three actions analyzed (fig. 2), which facilitates the interpretation of results. 


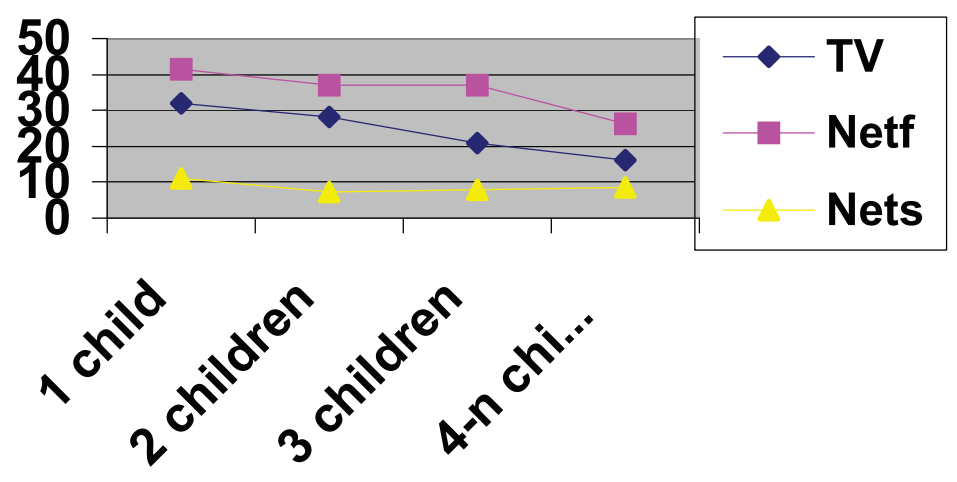

Fig. 2. Distribution curves for the data regarding the preference for spending free time at the weekend, according to the extension of the family

The data of the research reveal the influences exerted by the extension of the family on the options and preferences for spending free time at the weekend. The data indicate significant differences from a statistical point of view between the percentages of the choices made by the students who are single children and those coming from a large family, for two of the activities presented: watching a TV show $\left(\mathrm{A}_{\mathrm{TV}}=15,73 \%\right)$, respectively communicating with friends online $\left(A_{\text {Netp }}=14,17\right)$. Using the Internet for current school activities is not significantly influenced by the extension of the family, the differences being under four percentage points.

The almost lineal decreasing curve for (Netf) indicates the great need of single children or those having a brother/sister, to communicate with someone out of the family. Even if the weekend, especially Sundays, generally represents a time for family reunion, more than a third of the students coming from small families look for the company of friends. This fact reflects the crisis of the family, which becomes less capable of finding solutions to sustain the interrelations between its members and of identifying various ways in which a child can wish to be around his parents as much as possible.

Watching TV shows is something done together with the other members of the family, but in this case one notices significantly greater values for families less extended, too. The option for such an activity can also derive from a convenience of the family or from a lack of creativity in identifying diversified ways of spending together the time at the weekend. 
Starting from the fact that in Romania approximately $93 \%$ of the students at the pre-university levels opted for the study of the subject Religion and from the results of some sociological research indicating the fact that religiosity constitutes an important element in Romania and it is over the average of the central and Eastern European countries ${ }^{15}$, we made an analysis of the data according to the religious affiliation of the respondents. The analysis of the data starting from the students' religious denomination allows us to formulate some conclusions regarding the activities they choose for the weekend, a period which includes Sunday, a feast day for Christians. In this context, we consider the data collected from the respondents as being an average for the whole weekend, thus also for Sundays (table 6) ${ }^{16}$.

The preference for using ITC at the weekend, according to the religious denomination(\%)

\begin{tabular}{|c|c|c|c|}
\hline Confesiunea & $\begin{array}{l}\text { Watching } \\
\text { TV shows }\end{array}$ & $\begin{array}{l}\text { Communication } \\
\text { with friends } \\
\text { online }\end{array}$ & $\begin{array}{l}\text { Documenting } \\
\text { Internet } \\
\text { resources for } \\
\text { school } \\
\text { activities }\end{array}$ \\
\hline Orthodox & 28,22 & 37,76 & 8,58 \\
\hline Roman-Catholic & 36,36 & 18,18 & 9,09 \\
\hline Greek-Catholic & 29,41 & 47,08 & 5,88 \\
\hline Reformed Church & 33,33 & 35,89 & 12,82 \\
\hline Baptist & 13 & 53,33 & 0 \\
\hline Pentecostal & 12,5 & 17,5 & 5 \\
\hline
\end{tabular}

In table 6 we presented the data offered by the respondents belonging to the religious denominations that had higher percentages than $1 \%$ of the total (with a sum of percentages of approximately $98 \%$, in relation with the whole sample), distribution similar to the official one, at a national level. The data show the preference of the Orthodox, Greek-Catholic, Reformed, Baptist and Pentecostal students for communicating with friends online. The highest values were recorded in the case of the Baptist students $(53,33 \%)$,

15 http://www.pewforum.org/2017/05/10/religious-belief-and-national-belonging-in-centraland-eastern-europe/

${ }^{16}$ As the data of the present research have been collected during the school year, when students preoccupied by increasing their school performance appeal to extra preparation, often with a private teacher, including Sundays, we consider that the data recorded by us present greater values compared to the whole level of the year. 
and the lowest in the case of the Roman-Catholic and Pentecostal students (about 18\%). On the other hand, Roman-Catholic students prefer watching TV shows in greater percentages (almost 6-8, respectively 23 percentage points) than the Orthodox and Greek-Catholic, respectively Baptist and Pentecostal students. The low percentage of the students belonging to neoProtestant cults interested in computer-assisted education at the weekend can be due to the fact this activity is often considered work, current duty of the student, which can be translated in not respecting the day of rest or weekly feast.

The analysis of the data according to the level of education reveals significant differences concerning one aspect. This is documenting Internet resources, chosen mainly by high school students whose grades for the previous year had been between 9 and 10 (on a scale from 1 to 10, 10 being the highest one): $13,05 \%$, compared to $3,03 \%$,in the case of the high school students with a minimum level of education. The results indicate a greater preoccupation for studying and the use of free time for education. This must be corroborated with other aspects, such as, for example, the time these young people spend in the company of education means and the extent in which this activity draws them away from possible destructuring activities.

Another aspect taken into consideration by the present research refers to the number of hours students spent in front of the TV, respectively on the Internet. The only significant differences are found in the case of the students that prefer watching TV shows. In their case, one sees an increase of the percentage values for a growing number of watching hours, the maximum being for the interval 4-6 hours, according to the data in figure 3 .

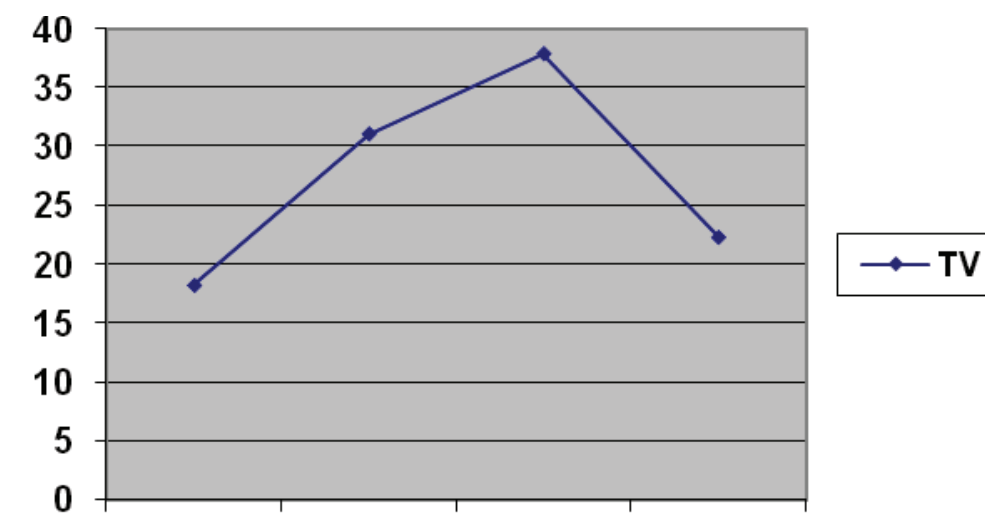

0-2 hours $2-4$ hours $4-6$ hours $6-n$ hours

Fig. 3. Distribution curve for the data concerning the number of hours spent in front of the TV by the students who opted for this activity 


\section{Conclusions}

The profile of the high school students who choose to spend part of their weekend in the company of the means offered by the technology of information and communications presents a series of particular aspects: 18year old girls, irrespective of their residence, single children or having a brother or sister prefer to watch TV; 16-year old boys or girls in the urban area, with a small number of family members prefer communication with friends online; irrespective of the number of children in the family or the residence, 18-year old girls choose documenting Internet resources for current school activities.

From our point of view, the essential questions the family should ask itself are: What does the weekend (still) represent for us? Why do children prefer to spend their weekend with friends not with the family? The fact that a great part of high school students tend to draw away from the activities specific to their own family for the weekend also show a crisis of the family, even a devaloriztion of it, but also the lack of a preoccupation to identify actions which meet better the expectations of these young people. Even in the undeniable context of the need for communication of young people today with friends or of the supplementary school activity and professional performance, the support high school students need in this important stage in their life from the family remains a central one.

\section{References:}

Opriş, D. (2016), Noile tehnologii ale informaţiei şi comunicaţilor în viaţa adolescenţilor. Provocări şi şanse pentru mediile educaţionale, in Dorin Opriş, Ioan Scheau, Octavian Moşin (editori), Educaţia din perspectiva valorilor. Tom X: Summa Paedagogica, Bucureşti, Eikon Publishing House.

Rateau, P. (2004), Metodele şi statisticile experimentale în ştiinţele umane, Iaşi, Polirom Publishing House.

Reada, J.C., Markopoulos, P. (2013), Child-computer interaction, in International Journal of Child-Computer Interaction, nr. 1.

Rotariu, T., Iluț, P. (2001), Ancheta sociologică şi sondajul de opinie. Teorie şi practică, Iaşi, Polirom Publishing House.

Voicu, M. (ed.) (2009), Credinţă şi practică religioasă în România, in I.C.C.V.: Valorile românilor, Newsletter, nr. 2. 